\section{Elective Surgical Treatment of} Duodenal Ulcer

SIR,-In the report on their controlled trial of truncal vagotomy and drainage for duodenal ulcer Mr. F. Kennedy and other members of Professor A. W. Kay's department at Glasgow (14 April, p. 71) record results which will be regarded by many surgeons as astonishing for their excellence. Thus no less than $86 \%$ of the patients after vagotomy and gastroenterostomy were classified by them as being in Visick categories I (excellent) and II (very good), a figure that rose to $92 \%$ when the outcome of reoperations for recurrent ulceration or bilious vomiting was included, leaving only $7 \%$ in category III (indifferent result) and $1 \%$ in category IV (failure). By comparison, in the Leeds/York controlled trial ${ }^{1}$ of three different operations for duodenal ulcer we considered that only $70 \%$ of our patients after vagotomy and gastroenterostomy qualified for Visick categories I and II, no less than $19 \%$ were placed in category III, and $11 \%$ had to be relegated to category IV; moreover, these proportions were not substantially altered by incorporating the results of reoperations.

It is a matter for conjecture as to why there should be this difference in the findings of these two inquiries, and several factors may be considered. The Glasgow trial involved a mean follow-up period of only four years, and $20 \%$ of the patients were lost to follow-up, while in the Leeds/York trial the follow-up was continued for five to eight years and all but $4 \%$ of the patients were traced. A difference in the quality of surgical skill in the two centres seems unlikely. More plausible is that the types of patients included in the two trials may have been somewhat different, or, most probable of all, that the stringency with which the Visick criteria were applied may have varied. But whatever the explanation for the divergence of results, there is certainly no reason to suppose that the accomplishments of the average surgeon throughout the country with this operation are more reliably reflected by the findings of the Glasgow trial than by those of the Leeds/York one.

On the basis of their inquiry the authors feel that truncal vagotomy with drainage represents virtually the acme of surgical achievement in the elective treatment of duodenal ulcer and that little scope remains for further improvement. Our results in the Leeds/York trial, and in other studies, ${ }^{2}$ on the contrary, indicate that after most operations for duodenal ulcer there is a hard core of between 25 and $30 \%$ of indifferent or frankly unsatisfactory results, which would seem to leave a fair amount of room for amelioration. Whether in fact proximal gastric vagotomy (syn: highly selective or parietal cell vagotomy) without drainage, which is currently the standard elective operation for duodenal ulcer in this department, will produce significantly better results remains to be established, for I entirely agree with Mr. Kennedy and his colleagues that the value of this new operation is still sub judice and will continue so until it has been more thoroughly assessed by longer followup studies, preferably as part of controlled randomized trials. I fully accedt that we in Leeds are open to severe criticism for not having seized the golden opportunity presented by our pioneer interest in this new operation to institute such a trial of it long ago. It is also perfectly true that proximal gastric vagotomy is technically a considerably more demanding operation than truncal vagotomy and drainage, but, with attention to detail and a certain amount of practice, it soon becomes quite feasible, if a little timeconsuming, in all but the grossly obese, even in the hands of a surgeon such as myself, whose time in the operating room is largely directed to other fields than gastric surgery. As for its suitability for men in training, my impression is that, whatever operation is being regularly performed by consultants, is soon done even better by their senior registrars.

Certainly, I should be failing in my duty if I did not reaffirm in the strongest term that our results with proximal gastric vagotomy without drainage in Leeds in ove 250 patients with duodenal ulcer in the past four years have been most encouraging to date, with no operative deaths, no significan gastric retention, virtually no diarrhoea, only two suspected and no proved recurren ulcers, and high Visick gradings. I think that it would indeed be a great pity if this new technique, which is based on such an idealistic conception-after all, it could be regarded as the realization of Lester Dragstedt's original dream of a pure neurectomy for peptic ulcer without surgical intervention in the stomach itself-and which shows so much initial clinical promise should be extinguished in its first flickering phase by a blast of scepticism from such a distinguished and respected figure of British gastroenterology as Andrew Kay.-I am, etc.,

\section{University Department of Surgery,}

\section{J. C. GOLIGHeR}

The General Infirmary,

Leeds

Goligher, J. C., et al., British Medical fournal, Goligher, J. C., et al., British Medical fournal,

\section{Stress and Myocardial Infarction}

SIR,-With reference to the study by $\mathrm{Mr}$. M. Shelton and Dr. J. Dominian of psychological stress in the wives of patients with myocardial infarction (14 April, p. 101), showing an increased incidence of depression and guilt in the wives, may I suggest that, in some cases, these were present before the attack and might have been a major cause of it?

Is it possible that a higher proportion than average of the men who have infarcts, the younger men in particular, have wives who are prone to depression and anxiety neurosis? Much is written of stress factors at work, even travelling to work, but to many men the greatest stress in their lives must be at home where they are continually striving to "make things better" in the misguided hope that it will improve their wives' attitude towards life. The more concerned the husband, the more will be his frustration and sense of failure. This is not to say that every infarct in a younger man with an anxiety-depressive wife is caused by the wife. It might be that the personality and life style that predispose a man to myocardial infarction also predispose his wife to anxiety neurosis and depression.

Possibly the facts that men are dying relatively younger than women, particularly of coronary artery disease, and that women are becoming more vocally discontent are related. Certainly it would be of interest, in a large number of cases of myocardial infarction in men, to study the wife's mental state before the attack. Perhaps future attacks might be prevented in some cases not by rinitrates for the husband, but rather by tricyclics for the wife.-I am, etc.,

Burnham, Bucks

B. N. J. DaILY

\section{David Livingstone}

SIR,-The courtesy and respect shown by David Livingstone to the African traditional healers, referred to in Professor George Shepperson's article (28 April, p. 232), extended to a willingness to submit himself to their ministrations. "When attacked by the fever myself, and wishing to ascertain what their practices were, I could safely intrust myself in their hands on account of their well-known friendly feelings." Of one such episode he writes, "I fondly hoped that they had a more potent remedy than our own medicines afford; but after being stewed in their vapour baths, smoked like a red herring over green twigs, and charmed 'secundem artem,' I concluded that I could cure the fever more quickly than they can." He considered the treatment helpful, however, with the addition of "a mild aperient in combination with quinine."

Livingstone's tact gave him the opportunity of proffering acceptable advice. "Any explanation in private was thankfully received by them, and wrong treatment changed into something more reasonable with cordial good will, if no one but the doctor and myself were present at the conversation."3 Whether, in that era, Livingstone's methods were a great advance upon those of his African colleague may be open to doubt, but his approach in developing rather than discarding the skills of traditional practitioners foreshadows more recent programmes especially in the fields of midwifery and psychiatry. ${ }^{4}-\mathrm{I}$ am, etc.,

Frank ASHWORTH

Liverpool Livingstone, D., Missionary Travels and $R e-$
searches in South Africa, p. 164. London, Ward Lock, 1899 .

2 ibid, p. 170.

3 ibid, p. 114.

Medical Care in Developing Countries, ed. $M$

King, pp. 3:10, 19:2,
University Press, 1966.

\section{Livingstone's Example}

SIR,-In your leading article (28 April, p. 196) it is stated that some chroniclers have wondered why Livingstone on occasions spoke of trade "as though it were part and parcel of the Christian religion."

We should learn that trading and Christianity are indeed synonymous. They are the pursuit of truth. Human beings claim rights, which is simply to say that they want conditions in which they can care for their minds and their bodies. If people expect rights they must also supply them for their neighbour, otherwise their neighbour has no source of his rights. Then we claim the lowest price, which is simply to say that we expect the most considerate sale. Individuals cannot 